\title{
Unit cell dimensions of some synthetic orthopyroxene group solid solutions
}

\author{
Yoshito Matsui" ${ }^{1}$, Yasuhiko Syono, Syun-iti Akimoto \\ and Kenzo Kitayama ${ }^{2)}$ \\ Institute for Solid State Physics, University of Tokyo, \\ Roppongi, Minato-ku, Tokyo, Japan
}

(Received June 23, 1968)

\begin{abstract}
Three series of solid solutions of orthopyroxene structure, ( $\mathrm{Fe}, \mathrm{Mg}$ ) $\mathrm{SiO}_{3}$, ( $\mathrm{Co}, \mathrm{Mg}) \mathrm{SiO}_{3}$ and $(\mathrm{Ni}, \mathrm{Mg}) \mathrm{SiO}_{3}$, were synthesized, using high pressure sintering technique. Unit cell parameters of the synthesized pyroxenes were determined at room temperature. The deviation from Vegard's law is remarkable for both iron and nickel pyroxene series, whereas almost absent for cobalt one. It is suggested that the dominant factors which determine the distribution of ions among nonequivalent sublattice sites are 1) the difference in effective sizes of both ions (for the case of $(\mathrm{Fe}, \mathrm{Mg}) \mathrm{SiO}_{3}$ ) and 2) the crystal field stabilization energy (for the case of $\left.(\mathrm{Ni}, \mathrm{Mg}) \mathrm{SiO}_{3}\right)$. The nearly ideal behavior of $(\mathrm{Co}, \mathrm{Mg}) \mathrm{SiO}_{3}$ is a result of the compensation between these two competing factors.
\end{abstract}

\section{INTRODUCTION}

In a previous paper on the unit cell parameters of olivine group solid solutions (Matsur and Syono, 1968), it was demonstrated that the deviation from Vegard's law is closely related to the site preference of $\mathrm{Mg}^{++}$and divalent transition metal ions over two nonequivalent sublattice sites. In the case of olivines, the degree of site preference is expected to increase in the order $(\mathrm{Fe}, \mathrm{Mg})_{2} \mathrm{SiO}_{4},(\mathrm{Co}, \mathrm{Mg})_{2} \mathrm{SiO}_{4}$ and $(\mathrm{Ni}, \mathrm{Mg})_{2} \mathrm{SiO}_{4}$, from the viewpoint of crystal field stabilization and ionic size. It was shown that the anomaly in cell edges, when plotted against chemical composition, became more pronounced in the same order.

Orthopyroxenes $\left(P b c a=D_{2 h}^{15}\right)$ also have two crystallographically nonequivalent sublattice sites for divalent cations, namely, $\mathbf{M}_{\mathbf{I}}$ and $\mathbf{M}_{\mathrm{II}}$ (notation by MоRIмото et al. (1960) is used in this paper). The $\mathrm{M}_{\mathrm{I}}$ site is surrounded by six nearest oxygens (two of which are "bridging" oxygens) with severely distorted configuration. The $\mathrm{M}_{\mathrm{II}}$ site is also surrounded by six nearest oxygens (all non-bridging) with fairly regular octahedral configuration. The mean $\mathrm{M}_{\mathrm{r}} \mathrm{O}$ distance is a little longer than the mean $\mathrm{M}_{\mathrm{II}} \mathrm{O}$ distance. For example, in orthoenstatite (MoRIMoto

1) On leave from Institute for Thermal Spring Research, Okayama University, Misasa, Tottori-ken, Japan.

2) On leave from Tokyo Institute of Technology, Ookayama, Meguro-ku, Tokyo, Japan. 
and Kото, 1968) the mean $\mathrm{M}_{\mathrm{r}}-\mathrm{O}$ and $\mathrm{M}_{\mathrm{II}} \mathrm{O}$ - distances are $2.158 \AA$ and $2.070 \AA$, respectively. Both sites have no symmetry elements except for the identical one, 1 . The ratio of numbers of $M_{I}$ and $M_{I I}$ is $1: 1$.

One may expect that the site preference is more marked in orthopyroxene than in olivine, since the difference in geometry between $M_{I}$ and $M_{I I}$ is greater in orthopyroxene than in olivine. Similar to the olivine solid solutions, the ordered structure of orthopyroxenes should influence the cell parameters. However, mainly due to the well known instability of some end members such as $\mathrm{FeSiO}_{3}, \mathrm{CoSiO}_{3}$ and $\mathrm{NiSiO}_{3}$, little has been known about the compositional dependence of cell parameters of orthopyroxene solid solutions. In the present report the unit cell dimensions of the orthopyroxene form of $(\mathrm{Fe}, \mathrm{Mg}) \mathrm{SiO}_{3},(\mathrm{Co}, \mathrm{Mg}) \mathrm{SiO}_{3}$ and $(\mathrm{Ni}, \mathrm{Mg}) \mathrm{SiO}_{3}$, synthesized under high pressures, are presented, and the compositional dependence of cell parameters is discussed with special reference to the site preference of cations in terms of crystal field effects and effective ionic sizes.

\section{EXPERIMENTAL}

Three orthopyroxene solid solution series of $(\mathrm{Fe}, \mathrm{Mg}) \mathrm{SiO}_{3},(\mathrm{Co}, \mathrm{Mg}) \mathrm{SiO}_{3}$ and $(\mathrm{Ni}, \mathrm{Mg}) \mathrm{SiO}_{3}$ were prepared by means of high pressure sintering technique, using a tetrahedral anvil type high pressure apparatus, since only one end member $\mathrm{MgSiO}_{3}$ of these solid solution series is stable at 1 atm and both $\mathrm{FeSiO}_{3}$ and $\mathrm{CoSiO}_{3}$ were found to be stable only at high pressures (Akimoto et al., 1964, 1965; LiNDSLEy et al., 1964). Moreover, this procedure is very suitable to avoid the complications due to the occurrence of metastable polymorphs such as clino- or proto-pyroxene, even in the $\mathrm{Mg}$-rich side of solid solutions.

Starting materials of $(\mathrm{Fe}, \mathrm{Mg}) \mathrm{SiO}_{3}$ solid solution series were prepared for every ca. $10 \%$ molar fraction, owing to the importance of this series in geological sciences. An equimolar mixture of silica and magnesium oxide of reagent grade was prepared by a pot mill in order to form $\mathrm{MgSiO}_{3}$ end member. The mixture was heated up to $1,700^{\circ} \mathrm{C}$ in a platinum-rhodium crucible, and was transformed to glassy material by subsequent quenching to room temperature. The glass thus obtained was finally devitrified at $1,200^{\circ} \mathrm{C}$ to get the clinoenstatite form of $\mathrm{MgSiO}_{3}$. As the other end member $\mathrm{FeSiO}_{3}$ cannot be synthesized under atmospheric conditions, ferrous oxide (wüstite) and silica were mixed so as to give the $\mathrm{Fe} / \mathrm{Si}$ ratio of 1 . Every solid solution member for the composition range from $10 \%$ to $60 \% \mathrm{FeSiO}_{3}$ was prepared by mixing these two end member materials in a required ratio and heated at $1,200^{\circ} \mathrm{C}$ under a controlled partial pressure of oxygen to make homogeneous pyroxene solid solutions. Three specimens with the composition of $70 \%, 80 \%$ and $90 \% \mathrm{FeSiO}_{3}$ were prepared by mixing equimolar amounts of olivine solid solutions ( $\mathrm{Fe}, \mathrm{Mg})_{2} \mathrm{SiO}_{4}$ with the corresponding composition and of silica.

In the case of synthesizing ( $\mathrm{Co}, \mathrm{Mg}) \mathrm{SiO}_{3}$ and $(\mathrm{Ni}, \mathrm{Mg}) \mathrm{SiO}_{3}$ solid solution series, we also used the clinoenstatite form of $\mathrm{MgSiO}_{3}$ as one of the end member materials. 
This clinoenstatite and cobalt or nickel orthosilicates plus silica were mixed in a desired proportion by grinding in an agate mortar. Specimens were prepared for every 25 mole per cent except for nickel-rich side of $(\mathrm{Ni}, \mathrm{Mg}) \mathrm{SiO}_{3}$. The use of $\mathrm{MgSiO}_{3}$, instead of the equimolar mechanical mixture of $\mathrm{SiO}_{2}$ plus $\mathrm{MgO}$, is indispensable in order to obtain a single phase pyroxene in a moderately short time duration at high pressures.

Powder mixtures were directly embedded in a graphite furnace which was placed in a pyrophyllite tetrahedron gasket as a pressure transmitting medium. Synthesizing conditions were $40 \mathrm{~kb}$ and $1,200^{\circ} \mathrm{C}$ for $(\mathrm{Fe}, \mathrm{Mg}) \mathrm{SiO}_{3}$ and $40 \mathrm{~kb}$ and $1,300^{\circ} \mathrm{C}$ for $(\mathrm{Co}, \mathrm{Mg}) \mathrm{SiO}_{3}$ and $(\mathrm{Ni}, \mathrm{Mg}) \mathrm{SiO}_{3}$. Specimens were held under these conditions for thirty minutes and quenched to room temperature by an abrupt cooling. The reduction of transition metal ions to the metallic states was quite negligible throughout the synthesis runs. In the case of nickel and cobalt pyroxene series, we repeated this procedure twice, after crushing and mixing each time, in order to obtain well crystallized materials.

Formation of a uniform solid solution was examined by the rapid scan X-ray diffraction pattern, which revealed a single phase orthopyroxene structure, free from any by-product such as clino- or proto-polymorph. It is to be noted here that both $\mathrm{NiSiO}_{3}$ and $\mathrm{Mg}_{0.25} \mathrm{Ni}_{0.75} \mathrm{SiO}_{3}$ specimens could not be transformed into a pyroxene structure. We tried to synthesize them under the conditions of up to $90 \mathrm{~kb}$ without success. Reaction product for $\mathrm{NiSiO}_{3}$ composition was either olivine or spinel form of $\mathrm{Ni}_{2} \mathrm{SiO}_{4}$ plus coesite, and that for $\mathrm{Ni}_{0.75} \mathrm{Mg}_{0.25} \mathrm{SiO}_{3}$ composition was olivine plus coesite plus pyroxene which may be the solid solution richest in nickel we could have. The composition of the most nickel-rich (single phase) orthopyroxene synthesized in the present study was $\mathrm{Ni}_{0.62} \mathrm{Mg}_{0.38} \mathrm{SiO}_{3}$. Composition of products was determined chemically by chelatometric titration for $\mathrm{Mg}, \mathrm{Fe}, \mathrm{Co}$, and $\mathrm{Ni}$. Results of chemical analyses were estimated to be accurate to the last digit presented.

Unit cell dimensions were determined from X-ray powder diffraction data measured at room temperature, using a Rigaku Denki Model DM 3 diffractometer equip. ped with a Geiger-Müller tube as a counting head. Calibration of goniometer was made using high purity silicon as an external standard. Goniometer scanning speed was $0.5^{\circ}(2 \theta)$ per minute. Iron $K_{\alpha_{1}}$ radiation was used throughout.

Lattice parameters were calculated by the least squares method, in which square sum of difference in $1 / d^{2}$ was the quantity to be minimized. Seventeen diffraction lines were used, whose $2 \theta$ angles range from $35^{\circ}$ to $89^{\circ}$. In Table 1 the results of $d$-spacing calculation for $\mathrm{MgSiO}_{3}, \mathrm{Fe}_{0.50} \mathrm{Mg}_{0.50} \mathrm{SiO}_{3}, \mathrm{FeSiO}_{3}, \mathrm{Co}_{0.50} \mathrm{Mg}_{0.50} \mathrm{SiO}_{3}, \mathrm{CoSiO}_{3}$ and $\mathrm{Ni}_{0.51} \mathrm{Mg}_{0.19} \mathrm{SiO}_{3}$ are shown as examples.

\section{Results AND Discussion}

The system $\mathrm{FeSiO}_{3}-\mathrm{MgSiO}_{3}$

The unit cell parameters are given in Table 2 and are shown graphically in 
Table 1. Examples of $d$-spacing calculation

\begin{tabular}{|c|c|c|c|c|c|c|c|c|c|c|c|c|}
\hline \multirow{3}{*}{$\begin{array}{c}\begin{array}{c}\text { Speci- } \\
\text { men }\end{array} \\
\text { Compo- } \\
\text { sition } \\
h k l\end{array}$} & \multirow{2}{*}{\multicolumn{2}{|c|}{$\begin{array}{c}\mathrm{MgP} 8 \\
\mathrm{MgSiO}_{3}\end{array}$}} & \multirow{2}{*}{\multicolumn{2}{|c|}{$\frac{50 \mathrm{Fs}}{{ }_{50} \mathrm{Mg}_{0 .}{ }_{50} \mathrm{SiO}_{3}}$}} & \multirow{2}{*}{\multicolumn{2}{|c|}{$\frac{100 \mathrm{Fs}}{\mathrm{FeSiO}_{3}}$}} & \multirow{2}{*}{\multicolumn{2}{|c|}{$\frac{\mathrm{CoP} 4}{\mathrm{Co}_{0.50} \mathrm{Mg}_{0.50 \mathrm{SiO}_{3}}}$}} & \multirow{2}{*}{\multicolumn{2}{|c|}{$\frac{\mathrm{CoP} 8}{\mathrm{CoSiO}_{3}}$}} & \multirow{2}{*}{\multicolumn{2}{|c|}{$\frac{\mathrm{NiP} 4}{\mathrm{Ni}_{0.51} \mathrm{Mgg}_{0.49} \mathrm{SiO}_{3}}$}} \\
\hline & & & & & & & & & & & & \\
\hline & $d_{\text {obs }}$ & $d_{\text {cale }}$ & $d$ & $d_{\text {calc }}$ & $d_{\mathrm{obs}}$ & $d_{\text {calc }}$ & $d_{\text {obs }}$ & $d$ & $d_{\mathrm{obs}}$ & $d_{\text {calc }}$ & $d$ & $d_{\text {cale }}$ \\
\hline 420 & 3.170 & 3.169 & 3.195 & 3.196 & 3.234 & 3.233 & 3.184 & 3.182 & 3.198 & 3.195 & 3.162 & 3.161 \\
\hline 321 & 2.940 & 2.939 & 2.966 & 2.965 & 2.994 & 2.995 & 2.953 & 2. & 2.963 & 2.962 & 2.932 & 2.931 \\
\hline 610 & 2.875 & 2.873 & 2.889 & 2.888 & 2.911 & 2.910 & $2.88 \mathrm{~L}$ & 2.879 & 2.889 & 2.886 & 2.869 & 2.868 \\
\hline 511 & 2.825 & 2.824 & 2.842 & 2.842 & 2.861 & 2.862 & 2.834 & 2.831 & 2.842 & 2.839 & & 2.819 \\
\hline 421 & 2.703 & 2.703 & 2.727 & 2.725 & 2.752 & 2.752 & 2.715 & 2.713 & 2.724 & 2.723 & & 2.697 \\
\hline 131 & 2.533 & 2.532 & 2.560 & 2.559 & 2.595 & 2.594 & 2.547 & 2.545 & 2.558 & 2.558 & & 2.523 \\
\hline 202 & 2.491 & 2.492 & 2.508 & 2.509 & 2.522 & 2.521 & 2.497 & 2.498 & 2.503 & 2.503 & 2.486 & 2.486 \\
\hline 531 & 2.0939 & 2.0931 & 2.1119 & 2.1117 & 2.1355 & 2.1355 & 2.1016 & 2.1021 & 2.1102 & 2.1106 & 2.0883 & 2.0876 \\
\hline 631 & 1.9561 & 1.9561 & 1.9728 & 1.9724 & 1.9935 & 1.9 & 1.9636 & 1.9638 & 1.9715 & 1.9713 & 1.9513 & 1.9513 \\
\hline 250 & 1.7319 & 1.7313 & 1.7517 & 1.7522 & 1.7804 & 1.7803 & 1.7421 & 1.7424 & 1.7522 & 1.7523 & 1.7 & 1.7253 \\
\hline 650 & 1.5249 & 1.5252 & 1.5410 & 1.5409 & 1.5620 & 1.5624 & 1.5338 & 1.5333 & 1.5405 & 1.5408 & 1.5204 & 1.5206 \\
\hline 1200 & 1.5194 & 1.5191 & 1.5258 & 1.5259 & 1.5365 & 1.5363 & 1.5216 & 1.5218 & 1.5252 & 1.5252 & 1.5178 & 1.5173 \\
\hline 1031 & 1.4843 & 1.4842 & 1.4877 & 1.4877 & 1.5122 & 1.5121 & 1.4886 & 1.4887 & 1.4937 & 1.4934 & 1.4808 & 1.4814 \\
\hline 060 & 1.4694 & 1.9695 & 1.4944 & 1.4942 & 1.5081 & 1.5077 & 1.4789 & 1.4792 & 1.4880 & 1.4878 & 1.4643 & 1.4643 \\
\hline 1131 & 1.3902 & 1.3906 & 1.3993 & 1.3996 & 1.4114 & 1.4117 & 1.3945 & 1.3946 & 1.3984 & 1.3987 & 1.3880 & 1.3881 \\
\hline
\end{tabular}

Table 2. Cell constants and unit cell volumes of synthetic orthopyroxene group solid solutions (at room temperature)

\begin{tabular}{|c|c|c|c|c|c|}
\hline Specimen & $\begin{array}{c}\text { Molar \% of } \\
\mathrm{MgSiO}_{3}\end{array}$ & $a(\AA)$ & $b(\AA)$ & $c(\AA)$ & $V\left(\AA^{3}\right)$ \\
\hline $\mathrm{MgP} 8$ & 100 & $18.230 \pm 0.002$ & $8.817 \pm 0.001$ & $5.181 \pm 0.002$ & $832.7 \pm 0.6$ \\
\hline $10 \mathrm{Fs}$ & 89 & $18.239 \pm 0.002$ & $8.830 \pm 0.001$ & $5.188 \pm 0.002$ & $835.5 \pm 0.4$ \\
\hline $20 \mathrm{Fs}$ & 79 & $18.265 \pm 0.002$ & $8.857 \pm 0.001$ & $5.200 \pm 0.002$ & $841.2 \pm 0.5$ \\
\hline $30 \mathrm{Fs}$ & 71 & $18.278 \pm 0.004$ & $8.881 \pm 0.002$ & $5.207 \pm 0.003$ & $845.2 \pm 0.9$ \\
\hline $40 \mathrm{Fs}$ & 61 & $18.294 \pm 0.005$ & $8.903 \pm 0.002$ & $5.215 \pm 0.005$ & $849.3 \pm 1.2$ \\
\hline $50 \mathrm{Fs}$ & 50 & $18.311 \pm 0.002$ & $8.926 \pm 0.001$ & $5.218 \pm 0.002$ & $852.9 \pm 0.5$ \\
\hline $60 \mathrm{Fs}$ & 39 & $18.329 \pm 0.003$ & $8.951 \pm 0.001$ & $5.226 \pm 0.003$ & $857.4 \pm 0.8$ \\
\hline $70 \mathrm{Fs}$ & 29 & $18.361 \pm 0.003$ & $8.976 \pm 0.001$ & $5.236 \pm 0.003$ & $862.9 \pm 0.8$ \\
\hline $80 \mathrm{Fs}$ & 19 & $18.377 \pm 0.003$ & $9.003 \pm 0.001$ & $5.236 \pm 0.003$ & $866.4 \pm 0.7$ \\
\hline $90 \mathrm{Fs}$ & 9 & $18.407 \pm 0.004$ & $9.033 \pm 0.002$ & $5.240 \pm 0.004$ & $871.2 \pm 1.0$ \\
\hline $100 \mathrm{Fs}$ & 0 & $18.436 \pm 0.002$ & $9.072 \pm 0.001$ & $5.243 \pm 0.002$ & $876.9 \pm 0.5$ \\
\hline $\mathrm{CoP} 2$ & 75 & $18.245 \pm 0.002$ & $8.846 \pm 0.001$ & $5.189 \pm 0.003$ & $837.5 \pm 0.6$ \\
\hline $\mathrm{CoP} 4$ & 50 & $18.261 \pm 0.002$ & $8.875 \pm 0.001$ & $5.193 \pm 0.002$ & $841.7 \pm 0.6$ \\
\hline $\mathrm{CoP} 6$ & 26 & $18.284 \pm 0.004$ & $8.899 \pm 0.002$ & $5.199 \pm 0.004$ & $846.0 \pm 0.9$ \\
\hline CoP 8 & 0 & $18.302 \pm 0.003$ & $8.927 \pm 0.001$ & $5.205 \pm 0.003$ & $850.4 \pm 0.7$ \\
\hline $\mathrm{NiP} 2$ & 73 & $18.219 \pm 0.003$ & $8.800 \pm 0.001$ & $5.173+0.003$ & $829.3 \pm 0.7$ \\
\hline $\mathrm{NiP} 4$ & 49 & $18.208 \pm 0.002$ & $8.786 \pm 0.001$ & $5.168 \pm 0.002$ & $826.7 \pm 0.6$ \\
\hline NiP 5 & 38 & $18.207+0.004$ & $8.780 \pm 0.002$ & $5.160 \pm 0.004$ & $824.8 \pm 0.9$ \\
\hline
\end{tabular}




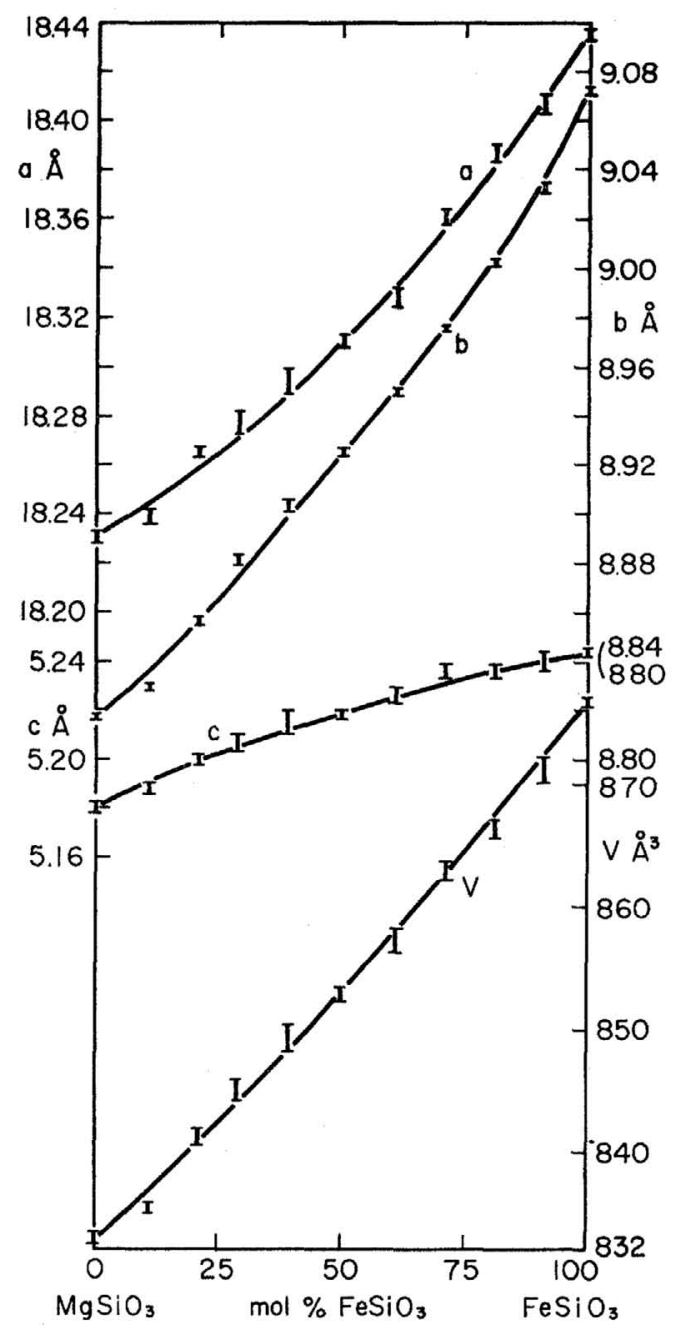

Fig. 1. Composition dependence of unit cell parameters $a, b$ and $c$ and unit cell volume $V$ of $(\mathrm{Fe}, \mathrm{Mg}) \mathrm{SiO}_{3}$ solid solutions with orthopyroxene structure.

Fig. 1. The lattice parameters of $\mathrm{MgSiO}_{3}$ are a little smaller than those reported by Stephenson et al. (1966), and those of $\mathrm{FeSiO}_{3}$ are slightly different from those by Акimoto et al. (1964), but agree with those by Burnham (Stephenson et al., 1966) as shown in Table 3. As is clearly seen in Fig. 1, the cell parameter curves display all the features characteristic of the intracrystalline exchange solid solutions just as have been noticed by MATsur and Syono (1968) on the (Co, $\mathrm{Mg})_{2} \mathrm{SiO}$, system. Deviations from Vegard's law are roughly proportional to $X_{\mathrm{Fe}}\left(1-X_{\mathrm{Fe}}\right)$, in other words, symmetrically increase as the molar compositions depart from pure end members. This behavior can be considered to be a natural consequence of pyroxene 
Table 3. Comparison of cell constants of three end members as reported by several authors

\begin{tabular}{llccll}
\hline \multicolumn{1}{c}{$a(\AA)$} & \multicolumn{1}{c}{$b(\AA)$} & $c(\AA)$ & \multicolumn{1}{c}{$V\left(\AA^{3}\right)$} & \multicolumn{1}{c}{ Reference } \\
\hline $\mathrm{MgSiO}_{3}$ & $18.2249 \pm 0.0013$ & $8.8149 \pm 0.0008$ & $5.1746 \pm 0.0008$ & $831.30 \pm 0.14$ & STEPHENSON et al. (1966) \\
& $18.230 \pm 0.002$ & $8.817 \pm 0.001$ & $5.181 \pm 0.002$ & $832.7 \pm 0.6$ & Present study \\
\hline $\mathrm{FeSiO}_{3}$ & $18.42 \pm 0.01$ & $9.068 \pm 0.005$ & $5.269 \pm 0.006$ & $880.1 \pm 2.0$ & AKIMOTo et al. $(1964)$ \\
& 18.431 & 9.080 & 5.238 & $876.68 \pm 0.54$ & BuRNHAM* \\
& $18.436 \pm 0.002$ & $9.072 \pm 0.001$ & $5.243 \pm 0.002$ & $876.9 \pm 0.5$ & Present study \\
\hline $\mathrm{CoSiO}_{3}$ & $18.30 \pm 0.01$ & $8.924 \pm 0.002$ & $5.216 \pm 0.006$ & $851.8 \pm 1.5$ & AKIMOTO et al. (1965) \\
& $18.302 \pm 0.003$ & $8.927 \pm 0.001$ & $5.205 \pm 0.003$ & $850.4 \pm 0.7$ & Present study \\
\hline
\end{tabular}

* Data cited by Stephenson et al. (1966).

structure, where the ratio of numbers of $M_{1}$ and $M_{I I}$ is $1: 1$, and of the well established preference of $\mathrm{Fe}^{++}$for $\mathrm{M}_{\mathrm{I}}$ (Morimoto et al., 1960; Ghose, 1965; Grose and Hafner, 1967; Bancroft et al., 1967; Morimoto and Güven, 1968).

Thermodynamic nonideality of this system has often been suspected. From the analysis of the partition relationship of $\mathrm{Fe}^{++}$and $\mathrm{Mg}^{++}$between naturally coexisting olivines and orthopyroxenes, RAMBERG and DeVorE (1951) concluded that orthopyroxene is a nonideal solution. In addition, they succeeded to detect the negative deviation from Vegard's law as to $a$ - and $b$-axes on natural specimens which strongly indicated the non-zero value of excess volume of mixing, $V_{\text {mix }}^{\mathrm{E}}$. CRAIG (1967) analyzed the relation between refractive indices and composition of synthetic monoclinic form of $(\mathrm{Fe}, \mathrm{Mg}) \mathrm{SiO}_{3}$ (Bowen and Schairer, 1935), and concluded that $V_{\mathrm{mix}}^{\mathrm{E}}=\psi X_{\mathrm{Fe}}\left(1-X_{\mathrm{Fe}}\right.$ ), where $\psi=-1.20 \mathrm{~cm}^{3} /$ mole.

The present data on $a$ - and $b$-edges agree essentially with those by RAMBERG and DeVore (1951). The effect of these negative deviations, however, is mostly cancelled out by the positive anomaly in $c$-edge, thereby resulting in rather small values of $V_{\mathrm{mix}}^{\mathrm{E}}$. Observed $V_{\mathrm{mix}}^{\mathrm{E}}$ for $X=0.5$ is about $-2 \AA^{3}$ per unit cell, this being only one fourth of CRAIG's estimate, i.e., $-8 \AA^{3}$ per unit cell. However, it is not

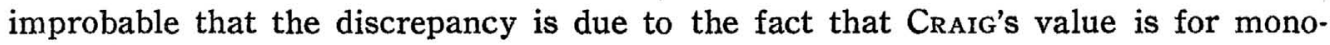
clinic form whereas the observed value is for orthorhombic form.

According to the ideal intracrystalline exchange solid solution model, the present system should be a nonideal one, with negative deviation from RaoulT's law (BANNo and MAtsur, 1966, 1967). Under the assumption that the Ca-rich pyroxene is the ideal solution of $\mathrm{CaFeSi}_{2} \mathrm{O}_{6}$ and $\mathrm{CaMgSi}_{2} \mathrm{O}_{6}$, Banno and MAtsur (1966) estimated the ratio $\left(\mathrm{Fe}^{++} / \mathrm{Mg}^{++}\right)_{\mathrm{MI}} /\left(\mathrm{Fe}^{++} / \mathrm{Mg}^{++}\right)_{\mathrm{MII}}$ in orthopyroxenes. Their results were in reasonable agreement with those by X-ray crystallography (MoRiмото and Кото, 1968) and by Mössbauer spectroscopy (Bancroft et al, 1967). Thus the nonideality of $(\mathrm{Fe}, \mathrm{Mg}) \mathrm{SiO}_{3}$ seemed to be a natural consequence of the site preference of $\mathrm{Fe}^{++}$ and $\mathrm{Mg}^{++}$ 
The picture described above, however, is not compatible with the result of direct thermodynamic activity measurements. NAFziger and MuAN (1967) claim that this system (where $X_{\mathrm{Fe}}<0.6$ ) is ideal within the experimental error at $1,250^{\circ} \mathrm{C}$, whereas Kitayama and Katsura (1968) state that the system is not ideal, but deviates from RAOULT's law positively at $1,204^{\circ} \mathrm{C}$. As a tentative explanation for this apparent inconsistency we may suggest here that, in the solutions of the present type, there are at least two competing factors: the negative one accompanying the ordered configuration (BANNo and MATSUI, 1967), and the positive one due to the substitution of ions of different size which results in the positive excess internal energy of the

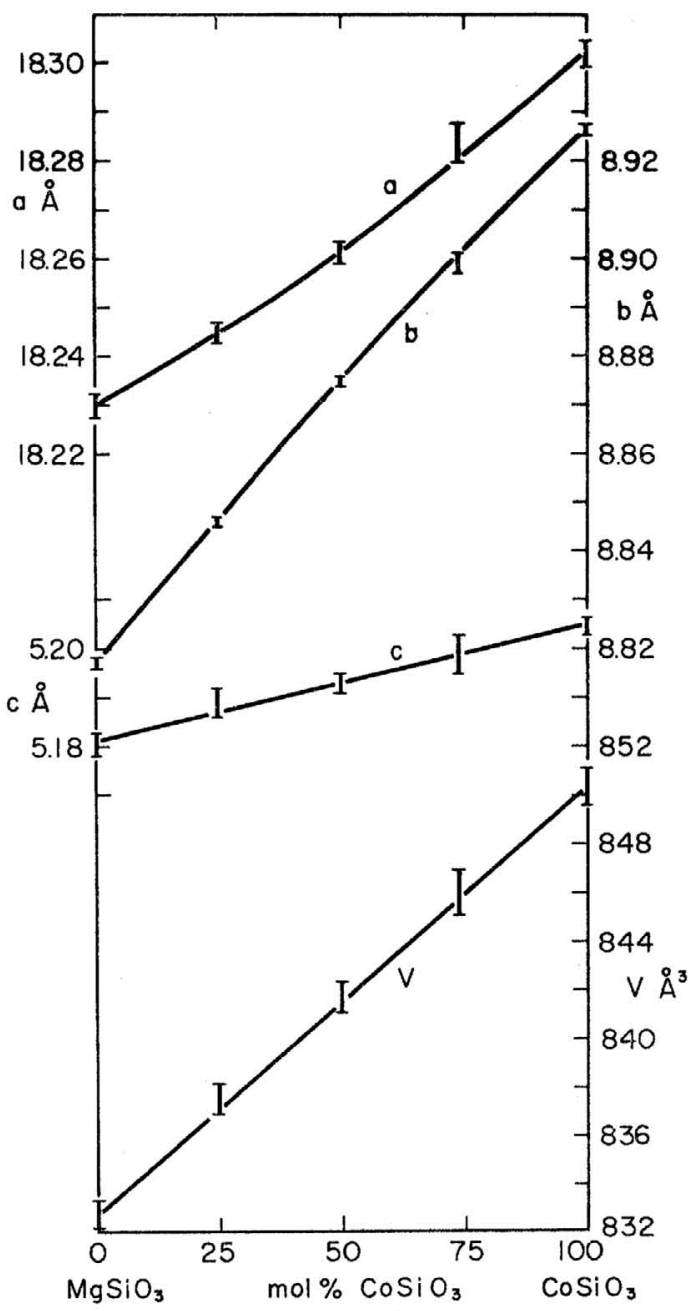

Fig. 2. Composition dependence of unit cell parameters $a, b$ and $c$ and unit cell volume $V$ of ( $\mathrm{Co}, \mathrm{Mg}) \mathrm{SiO}_{3}$ solid solutions with orthopyroxene structure. 
system, as suggested by NAGASAwA (1966).

Some peculiar anomalies can be found in the Mg-rich side of this solid solution. Unfortunately, the accuracies of measurements are not high enough to judge whether these anomalies are real or not.

The system $\mathrm{CoSiO}_{3}-\mathrm{MgSiO}_{3}$

Data for this system are given in Table 2 and are shown graphically in Fig. 2. The $\mathrm{Co}^{++}$ion has smaller size than $\mathrm{Fe}^{++}$, and is more strongly stabilized by an octahedral crystal field than $\mathrm{Fe}^{++}$. Therefore it is expected that $\mathrm{Co}^{++}$prefers the $\mathrm{M}_{\mathrm{II}}$ site more strongly than $\mathrm{Fe}^{++}$. This view is fully supported by the present data. As is seen in Fig. 2, there are little anomalies in the cell edge curves, suggesting rather uniform distribution of $\mathrm{Co}^{++}$over $\mathrm{M}_{\mathrm{I}}$ and $\mathrm{M}_{\mathrm{rI}}$ sites. It is highly likely that the tendency to prefer $\mathrm{M}_{\mathrm{I}}$, because of larger ionic size of this ion relative to $\mathrm{Mg}^{++}$, is largely cancelled out by the tendency to prefer $\mathrm{M}_{\mathrm{II}}$ due to the strong crystal field effect. This situation is analogous to that of the $\mathrm{Fe}_{2} \mathrm{SiO}_{4}-\mathrm{Mg}_{2} \mathrm{SiO}_{4}$ system in the olivine series.

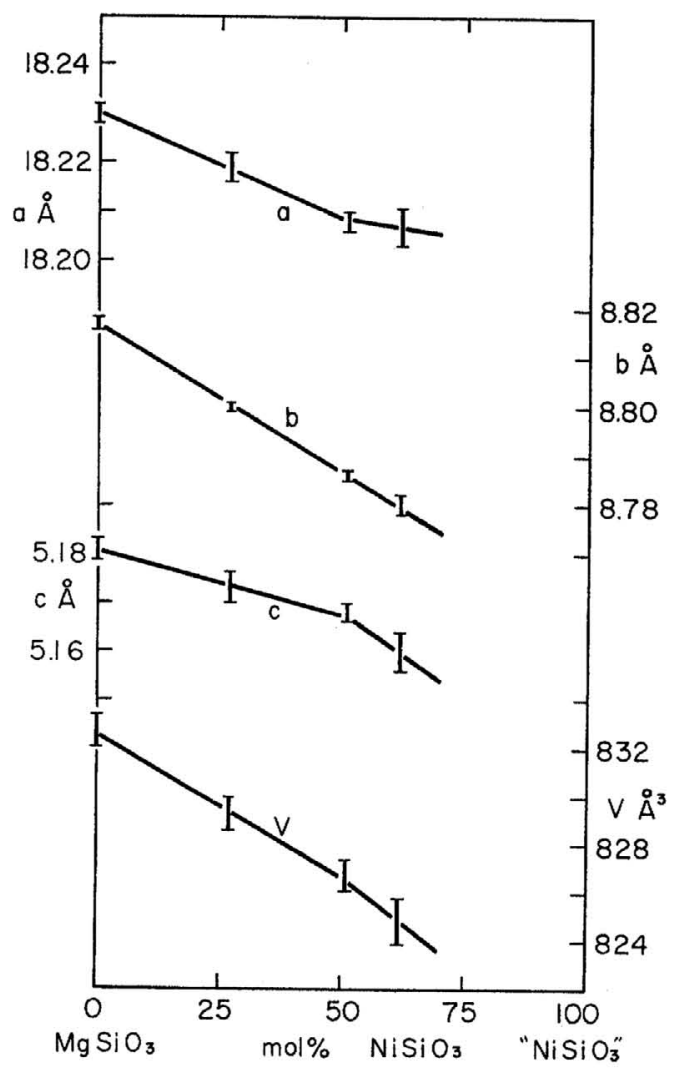

Fig. 3. Composition dependence of unit cell parameters $a, b$ and $c$ and unit cell volume $V$ of $(\mathrm{Ni}, \mathrm{Mg}) \mathrm{SiO}_{3}$ solid solutions with orthopyroxene structure, 
The system " $\mathrm{NiSiO}_{3}$ "- $\mathrm{MgSiO}_{3}$

As has been described in the experimental section, we could not obtain pure $\mathrm{NiSiO}_{3}$ of pyroxene structure. Values of unit cell dimensions are presented in Table 2 and are plotted against composition in Fig. 3. Owing to the absence of one of end members, discussion cannot be made definitely. Nevertheless, it seems probable that cell edge curves show remarkable inflexions at the composition of $\mathrm{Ni}: \mathrm{Mg}=1: 1$. It is interesting to note that the general features resemble those of the $(\mathrm{Fe}, \mathrm{Mg}) \mathrm{SiO}_{3}$ system. In both systems $a$-edge shows negative deviation and $c$-edge shows positive deviation.

Since the octahedral crystal field stabilization is greatest for $\mathrm{Ni}^{++}$among ions treated in this paper, and the effective ionic size of $\mathrm{Ni}^{++}$is smaller than that of $\mathrm{Mg}^{++}$in most oxygen compounds, it is natural to suppose that $\mathrm{Ni}^{++}$very strongly prefers the $\mathrm{M}_{\mathrm{II}}$ site. Accordingly the resemblance in cell edge anomaly pointed above may be more than a fortuitous coincidence, but rather a logical consequence of similarity in mode of site preference, i.e., the larger ion prefers the $M_{I}$ site in both cases.

The compound $\mathrm{CaNiSi}_{2} \mathrm{O}_{6}$ with diopside structure has been reported to be stable under the atmospheric pressure (GJEssing, 1947). This fact corroborates the $M_{\text {II }}$ preference of $\mathrm{Ni}^{++}$as deduced here. Probably the stabilization of $\mathrm{Ni}^{++}$in $\mathrm{M}_{I}$ of pyroxene structure is far less as compared to that in, for example, NiO or spinel form of $\mathrm{Ni}_{2} \mathrm{SiO}_{4}$ and even less than that in olivine form of $\mathrm{Ni}_{2} \mathrm{SiO}_{4}$. This relative instability may be a major cause of extreme instability of $\mathrm{NiSiO}_{3}$ of pyroxene structure.

\section{Concluding Remarks}

It is well known that the octahedral stabilization energy increases in the order of $\mathrm{Mg}^{++}<\mathrm{Fe}^{++}<\mathrm{Co}^{++}<\mathrm{Ni}^{++}$, whereas the ionic size decreases in the order of $\mathrm{Fe}^{++}$ $>\mathrm{Co}^{++}>\mathrm{Mg}^{++} \geq \mathrm{Ni}^{++}$. Since the larger $\mathrm{M}_{\mathrm{I}}$ site is more distorted than the smaller $\mathrm{M}_{\mathrm{II}}$ site in the pyroxene structure, these two factors are competing with each other in the distribution of $\mathrm{Mg}^{++}$and divalent transition metal ions between these two sites. As the distortion of $M_{I}$ site in the orthopyroxene structure is very severe and the difference in size between $M_{I}$ and $M_{I I}$ sites is more pronounced than that between $M_{I}$ and $M_{I I}$ in olivine, the contrast between two nonequivalent sites $M_{I}$ and $M_{I I}$ in pyroxene is far more remarkable than that in the olivine structure. This situation is reflected in the nonexistence of $\mathrm{NiSiO}_{3}$ pyroxene (cf. the existence of $\mathrm{Ni}_{2} \mathrm{SiO}_{4}$ olivine) and in the almost ideal behavior of ( $\mathrm{Co}, \mathrm{Mg}) \mathrm{SiO}_{3}$, in which two competing factors, crystal field effect and ionic size, are considered to be just cancelled out. (N.B. Such situation is realized for $(\mathrm{Fe}, \mathrm{Mg})_{2} \mathrm{SiO}_{4}$ in the case of the olivine solid solutions.)

The least squares refinement of cell parameters was performed at the Computer Center of the Institute for Solid State Physics, University of Tokyo. 


\section{REFERENCES}

Akimoto, S., Fujisawa. H. and KatSura, T. (1964) Synthesis of $\mathrm{FeSiO}_{3}$ pyroxene (ferrosilite) at high pressures. Proc. Japan Acad. 40, 272-275.

AKImoto, S., Katsura, T., SYONO, Y.. FujISAWA, H. and KomAdA, E. (1965) Polymorphic transition of pyroxenes $\mathrm{FeSiO}_{3}$ and $\mathrm{CoSiO}_{3}$ at high pressures and temperatures. J. Geophys. Res. 70, 5269-5278.

BANCROFT, G. M., MADDOCK, A. G. and BURNS, R. G. (1967) Application of the Mössbauer effect to silicate mineralogy, I. Iron silicates of known structure. Geochim. Cosmochim. Acta. 31, 2219-2246.

Banno, S. and Matsui, Y. (1966) Intracrystalline exchange equilibrium in orthopyroxene. Proc. Japan Acad. 42, 629-633.

BANNO, S. and MATSUI, Y. (1967) Thermodynamic properties of intracrystalline exchange solid solution. ibid. 43, 762-767.

Bowen, N. L. and Schairer, J. F. (1935) The system, MgO-FeO-SiOn. Am. J. Sci. 29, $151-217$.

CRAIG, H. (1967) Excess volumes and refractive indices in simple silicate mixtures with additive refractivity (Abstract). Trans. Am. Geophys. Union 48, 234.

GJEssing, L. (1941) Contribution a l'étude des métasilicates. Norsk Geol. Tiasskrift 20, 265-267.

GHOSE, S. (1965) $\mathrm{Mg}^{2+}-\mathrm{Fe}^{2+}$ order in an orthopyroxene, $\mathrm{Mg} 0 .{ }_{93} \mathrm{Fe}_{1,07} \mathrm{Si}_{2} \mathrm{O}_{6}$. Z. Krist. 122, 81-99.

GHOSE, S. and HAFNER, S. (1967) $\mathrm{Mg}^{2+}-\mathrm{Fe}^{2+}$ distribution in metamorphic and volcanic orthopyroxenes. ibid. 125, 157-162.

KITAYAMA, K. and KATSURA, T. (1968) Activity measurements of orthosilicaie and metasilicate solid solutions, I. $\mathrm{Mg}_{2} \mathrm{SiO}_{4}-\mathrm{Fe}_{2} \mathrm{SiO}_{4}$ and $\mathrm{MgSiO}_{3}-\mathrm{FeSiO}_{3}$ at $1204^{\circ} \mathrm{C}$. Bull. Chem. Soc. Japan 41, 1146-1151.

LINDSLEY, D. H., DAVIS, B. T. C. and MACGREGor, I. D. (1964) Ferrosilite (FeSiO $)_{3}$ : Synthesis at high pressures and temperatures. Science 144, 73-74.

MATSUI, Y. and SYONO, Y. (1968) Unit cell dimensions of some synthetic olivine group solid solutions. Geochem. J. 2, 51-59.

Morimoto, N., APpleman, D. E. and Evans, H. T., Jr. (1960) The crystal structures of clinoenstatite and pigeonite. Z. Krist. 114, 120-147.

MoRimoto, N. and Güven, N. (1968) Refinement of the crystal structure of pigeonite, $\left(\mathrm{Mg}_{0.39}\right.$ $\left.\mathrm{Fe}_{0.52} \mathrm{Ca0.09}\right) \mathrm{SiO}_{3}$. Carnegie Inst. Year Book 66, 494-497.

MORIMOTO, N. and Кото, K. (1968) The crystal structure of orthoensatite. Z. Krist. (to be published).

NAFZIGER, R. H. and MUAN, A. (1967) Equilibrium phase compositions and thermodynamic properties of olivines and pyroxenes in the system $\mathrm{MgO}$-"FeO"-SiO . Am. Mineralogist 52, 1364-1385.

NAGASAWA, H. (1966) Trace element partition coefficient in ionic crystals. Science 152, 767-769.

RAMBERG, H. and DEVORE, G. (1951) The distribution of $\mathrm{Fe}^{++}$and $\mathrm{Mg}^{++}$in coexisting olivines and pyroxenes. J. Geol. 59, 193-210.

Stephenson, D. A., SClaR, C. B. and SMith, J. V. (1966) Unit cell volumes of synthetic orthoenstatite and low clinoenstatite. Mineral. Mag. 35, 838-846. 